DOI 10.14746/ps.2016.1.28

Uniwersytet im. Adama Mickiewicza w Poznaniu

\title{
SIPRI YEARBOOK 2015
}

SIPRI (Sztokholmski Międzynarodowy Instytut Badań nad Pokojem) systematycznie, od 1966 roku, publikuje rocznik poświęcony takim problemom jak: światowe wydatki zbrojeniowe, międzynarodowe transfery broni, produkcja zbrojeniowa, siły nuklearne, konflikty zbrojne czy multilateralne operacje pokojowe. Zawarte w nim analizy opierają się na aktualnym (najnowszym) stanie wiedzy m.in. z zakresu kontroli broni, pokoju i bezpieczeństwa międzynarodowego. Ostatnie wydanie (Rocznik 2015) dotyczy 2014 roku i koncentruje się na trzech, wydaje się najważniejszych z punktu widzenia badań nad pokojem, kwestiach: bezpieczeństwo i konflikty, wydatki wojskowe i uzbrojenie oraz nieproliferacja, kontrola zbrojeń i rozbrojenie. Niniejsze opracowanie, ze względu na objętość „SIPRI Yearbook 2015”, zawiera uporządkowane chronologicznie najważniejsze tendencje opublikowane w roczniku.

We wstępie podkreśla się najważniejszy wątek charakterystyczny dla 2014 roku, kiedy to w wyniku upadku państwowości w Iraku, Libii i Syrii podmioty zewnętrzne (np. mocarstwa, organizacje międzynarodowe) coraz bardziej niechętnie chcą brać na siebie odpowiedzialność za utrzymanie bezpieczeństwa wewnętrznego konkretnych państw i po zeszłorocznych doświadczeniach straciły pewność, że tego rodzaju interwencje militarne mogą odgrywać konstruktywną rolę. Co więcej część z tych interwencji opierała się na fałszywych przesłankach (zagrożeniach), a przecież prowadzą one do nieodwracalnych zmian w systemie politycznym, strukturze instytucjonalnej czy w samych społeczeństwach. Ponadto w Europie doszło do renesansu instytucji państwa jako fundamentu bezpieczeństwa, głównie poprzez konflikt na Ukrainie, który w zaledwie kilka miesięcy i mimo gęstej sieci konwencji, umów prawnych czy politycznych porozumień zmarginalizował instytucje międzynarodowe. Wydaje się, że na Starym Kontynencie powróciła koncepcja bezpieczeństwa oparta na tradycyjnej formie polityki siły i obecnie warta rozważenia pozostaje wątpliwość w jakim stopniu multilateralizm, jako podejście do zarządzania bezpieczeństwem, stracił na znaczeniu. Gwoli ścisłości trzeba podkreślić, że w 2014 r. Rada Bezpieczeństwa ONZ była bardziej aktywna niż kiedykolwiek wcześniej, co może być dostrzegane jako próba jej instytucjonalnej ewolucji, choć nie przerodziło się to w zwiększenie skuteczności i szybkości w reagowaniu na zagrożenia międzynarodowego pokoju i bezpieczeństwa. Najważniejsza konkluzja z 2014 roku sprowadza się do potwierdzenia przełamania pozytywnego trendu zmniejszania przemocy i bardziej skutecznego zarządzania konfliktami, charakterystycznego dla minionej dekady.

W pierwszej części rocznika poświęconej bezpieczeństwu i konfliktom zbrojnym w szczegółowy sposób potwierdzono odwrócenie się ww. trendu. W Syrii i Iraku doszło do intensyfikacji działań zbrojnych oraz powstania i późniejszego wzrostu znaczenia tzw. Państwa Islamskiego (IS, ISIS, ISIL), co doprowadziło do znacznego osłabienia legitymizacji władzy w tym regionie i wzmocnienia ugrupowań lojalnych wobec wybranych aktorów międzynarodowych. W konsekwencji, mimo sukcesów ko- 
alicji przeciw ISIS, może okazać się, że ustanowienie międzynarodowego pokoju i bezpieczeństwa w tym regionie będzie długoterminowe i jedynie tymczasowe. Kolejne rozważania objęy obszar Europy, kiedy wyartykułowano negatywne implikacje konfliktu zbrojnego na Ukrainie, szczególnie jego konsekwencje w kontekście multilateralizmu. Dotychczasowe europejskie wysiłki na rzecz ustanowienia zasad, procedur, ram i instytucji zapobiegania i zarządzania kryzysami szybko w 2014 roku okazały się niewystarczające, a wręcz nieadekwatne do wyzwań. Co więcej, zawiodly środki budowy zaufania i bezpieczeństwa, co pobudziło państwa Europy do zwiększenia wydatków na zbrojenia, szczególnie sąsiadów Federacji Rosyjskiej.

Wstępne wnioski wskazują, że w 2014 roku było więcej wojen niż w jakimkolwiek innym analogicznym okresie obecnego stulecia. Ten trend odnosi się także, choć w mniejszym stopniu, do większej brutalności ze strony uzbrojonych ugrupowań, jak w przypadku Boko Haram w Nigerii czy tzw. Państwa Islamskiego. Równocześnie wzrosła liczba operacji pokojowych, podobnie jak w 2013 r., lecz całkowita liczebność personelu stabilizacyjnego znów spadła. Pomimo nowych wyzwań i trudności, a nawet coraz częstszej krytyki tego rodzaju działań, to nadal operacje pokojowe stanowią użyteczne narzędzie zarządzania konfliktami. Jednak coraz bardziej wymagające misje, wysokie oczekiwania międzynarodowe i zmiany geopolityczne zmusiły Sekretarza Generalnego do kompleksowego przeglądu operacji pokojowych ONZ.

W kontekście europejskim 2014 rok zdominował eskalowany kryzys na Ukrainie, który pogorszył, wydaje się wręcz nieodwracalnie, polityczne i instytucjonalne relacje między Rosją a jej zachodnimi sąsiadami. Doszło także do odnowy wojskowego wymiaru bezpieczeństwa transatlantyckiego, choć przez ostatnie dwie dekady Europejczycy przyzwyczaili się do lagodnego środowiska pod względem bezpieczeństwa i nie doceniali, a z pewnością ignorowali, potrzeby przygotowywania się na zagrożenia militarne.

W rejonie Azji Wschodniej również narasta napięcie między państwami, praktycznie od 2008 roku, głównie z powodu obaw przed morskimi aspiracjami terytorialnymi Chin, proliferacją broni jądrowej, wojskową akumulacją sił i środków oraz skutkami ubocznymi niestabilnego Afganistanu i Pakistanu. Modernizacja militarna Państwa Środka napędza Stany Zjednoczone do dalszego zacieśniania współpracy z wybranymi państwami tego regionu, a ponadto chińska aktywność na obszarach spornych Morza Południowochińskiego i Morza Wschodniochińskiego zmusza do kontestacyjnej polityki zagranicznej szczególnie Wietnam i Filipiny. Wiele nowych inicjatyw dyplomatycznych, jak tworzenie alternatywnych do zachodnich odpowiedników instytucji finansowych i politycznych w Azji, podważa dotychczasowy amerykański New World Order i marginalizuje zdolność oddziaływania USA na zarządzanie i rozwiązywanie konfliktów w tym regionie. Japonia sprzyja amerykańskim próbom ograniczania Państwa Środka i administracja Abe, wbrew oczekiwaniom czéści społeczeństwa japońskiego, „normalizuje" politykę obronna, odchodzi od standardów ustanowionych po II wojnie światowej i zwiększa swój wkład w bezpieczeństwo regionalne. Natomiast Rosja, chcąc zapobiec dalszemu osłabianiu swoich wpływów w tej części świata, stara się kultywować dotychczasową współpracę, choć mało prawdopodobne, by obecnie była w stanie zwiększyć wpływy strategiczne w północnej części Azji Wschodniej.

Druga część rocznika (wydatki wojskowe i uzbrojenie) zaczyna się od oszacowania światowych wydatków wojskowych na poziomie 1776 miliardów dolarów w 2014 r., co 
stanowi 2,3 procent światowego produktu krajowego brutto lub w przeliczeniu 245 dolarów za osobę. Łączne wydatki byly o 0,4 procent niższe w ujęciu realnym niż w 2013 r., ale dozbrajanie nadal gwaltownie rośnie w Afryce, Europie Wschodniej i na Bliskim Wschodzie. Ujemny wynik światowych wydatków na zbrojenia wynika głównie ze zmniejszania się zaangażowania Stanów Zjednoczonych, wycofywania się amerykańskiej armii z Afganistanu. Nadal pięciu największych dostawców w latach 2010-2014 (USA, Rosja, ChRL, Niemcy i Francja) wytwarza 74 procent całkowitego obrotu globalnego eksportu broni. Niestety w 2014 roku potwierdził się trend ograniczania przejrzystości światowego transferu broni i liczba państw zgłaszających do rejestru ONZ przywóz i wywóz broni konwencjonalnej (UNROCA) ponownie zmniejszyła się. Tylko nieco ponad jedna czwarta wszystkich członków ONZ odpowiedziała na wniosek Sekretarza Generalnego do przekazania podstawowych danych na temat importu i eksportu tego towaru. W okresie 2009-2013 część z największych dostawców broni nie zgłasza swojej aktywności do UNROCA, nawet tych transferów zarejestrowanych przez SIPRI. W tym kontekście najważniejszym wydarzeniem poprzedniego roku było wejście w życie Traktatu o handlu bronią (ATT) w grudniu 2014 r., choć nie gwarantuje on poprawy standardów. Obecnie kluczowym zagadnieniem, nieuregulowanym tą umową międzynarodowa, stał się problem dostaw broni do państw zaangażowanych $\mathrm{w}$ konflikt z udziałem aktorów niepaństwowych, np. w wojnie z Państwem Islamskim.

W kwestii globalnych sił nuklearnych, na początku 2015 r., dziewięć państw (USA, Rosja, Wielka Brytania, Francja, ChRL, Indie, Pakistan, Izrael i KRLD) posiadały około 15850 sztuk broni jądrowej, z których 4300 zostało wdrożone do sił operacyjnych, a około 1800 są utrzymywane w stanie podwyższonej gotowości operacyjnej. Łączna liczba głowic jądrowych na świecie spadła, głównie z powodu Rosji i USA od kiedy ustawicznie dążą one do zredukowania swojego arsenału jądrowego. Razem, ich zasoby stanowią ponad 90 procent światowej broni jądrowej, choć trzeba podkreślić pewien brak wiarygodnych danych w tej kwestii w wyniku niedostarczania informacji publicznej przez część mocarstw atomowych.

W trzeciej części rocznika (nieproliferacja, kontrola zbrojeń i rozbrojenie) podkreśla się, iż kluczowym celem wysiłków w ramach nierozprzestrzeniania broni jądrowej jest i będzie program nuklearny Iranu generujący długotrwałe międzynarodowe obawy. W całym 2014 r. Iran kontynuuje wdrażanie porozumienia z Międzynarodową Agencją Energii Atomowej (MAEA) w odniesieniu do Traktatu o nierozprzestrzenianiu broni jądrowej (NPT). Organizacja ta nie może jednak zapewnić, że caly irański materiał jądrowy będzie wykorzystany $w$ celach pokojowych. Z kolei w relacjach amerykańsko-rosyjskich nadal panuje impas w kwestii podpisanego w 2010 r. Nowego START-u (ang. New Strategic Arms Reduction Treaty), a nawet oba państwa zaczęły wzajemnie oskarżać się o nieprzestrzeganie Traktatu o całkowitej likwidacji pocisków rakietowych średniego i krótkiego zasięgu z 1987 roku. Natomiast w czasie Konferencji Rozbrojeniowej, jedynym wielostronnym forum negocjacyjnym w kwestii kontroli zbrojeń i rozbrojenia, po raz kolejny nie udało się uzgodnić programu pracy i tym samym nie rozpoczęto negocjacji w sprawie jakiegokolwiek punktu porządku obrad.

W części poświęconej redukcji zagrożeń związanych z chemicznymi i biologicznymi materiałami ukazano opóźnienia i braki proceduralne państw oraz organizacji międzynarodowych, w tym Światowej Organizacji Zdrowia, w neutralizowaniu za- 
grożenia wywołanego wirusem ebola w Zachodniej Afryce, gdzie na 20000 przypadków zachorowań zmarło 8000 ludzi. Z kolei Organizacja do spraw Zakazu Broni Chemicznej (OPCW), która monitoruje światowe przestrzeganie Konwencji o zakazie broni chemicznej (ang. Chemical Weapons Convention), nadal koordynuje działania międzynarodowe w celu usunięcia środków chemicznych z Syrii. Prowadzi także misję rozpoznawczą w tym państwie w kwestii ponownego użycia broni chemicznej (chloru).

W 2014 r. kontrola broni konwencjonalnej nadal była w pełni wykorzystywanym narzędziem w dziedzinie bezpieczeństwa i budowy pokoju. Ogólnie rzecz biorąc, państwa podtrzymują istotną rolę kontroli zbrojeń jako ważnego elementu swojej polityki bezpieczeństwa. Niestety zamiast podejmować zrównoważone podejście w tym aspekcie, to coraz więcej państw woli głównie polegać na własnych siłach zbrojnych i dąży do dozbrojenia. Nadal największym wyzwaniem dla obowiązujących konwencji o kontroli zbrojeń stanowi ciągłe stosowanie niehumanitarnej broni w konfliktach przez państwa niebędące stronami konwencji oraz przez podmioty niepaństwowe.

W zakończeniu ostatniej trzeciej części Rocznika podkreśla się znaczący wzrost liczby ćwiczeń wojskowych organizowanych na dużą skalę przez Rosję w krótkim czasie oraz rosnącą liczbę przypadków zaangażowania rosyjskich samolotów oraz okrętów wojennych w potencjalnie niebezpieczne manewry (prowokacje). Te dwa elementy spowodowały zwiększenie liczby i także różnorodności ćwiczeń wojskowych w ramach Paktu Północnoatlantyckiego (NATO) w najbliższych latach.

Na końcu rocznika SIPRI dołączono aneksy (syntetyczne i chronologiczne).

\title{
STRESZCZENIE
}

Komentarz poświęcono „SIPRI YEARBOOK 2015” i zawartym w nim najważniejszym tendencjom potwierdzonych najbardziej aktualną wiedzą. Coroczne opracowanie w kompleksowy sposób ukazuje aktywność aktorów międzynarodowych w kwestii światowych wydatków zbrojeniowych, międzynarodowych transferów broni, produkcji zbrojeniowej, sił nuklearnych, konfliktów zbrojnych czy multilateralnych operacji pokojowych.

Słowa kluczowe: Sztokholmski Międzynarodowy Instytut Badań nad Pokojem, „Rocznik SIPRI 2015", zbrojenia, rozbrojenie, bezpieczeństwo międzynarodowe

\section{SIPRI YEARBOOK 2015}

\begin{abstract}
The commentary includes the most important trends confirmed the current knowledge in the „SIPRI Yearbook 2015”. Every year the organization in a comprehensive manner shows the activity of international actors in terms of world military expenditure, international arms transfers, arms production, nuclear forces, armed conflicts and multilateral peace operations.
\end{abstract}

Key words: Stockholm International Peace Research Institute, „SIPRI Yearbook 2015”, Armaments, Disarmament, International Security 